\title{
The labour market for histopathologists in KwaZulu- Natal: Emerging issues
}

\author{
Author: \\ Shaun Ruggunan ${ }^{1}$ \\ Affiliation: \\ ${ }^{1}$ School of Management, \\ Information Technology and \\ Governance, University of \\ KwaZulu-Natal, South Africa \\ Correspondence to: \\ Shaun Ruggunan \\ Email: \\ ruggunans@ukzn.ac.za \\ Postal address: \\ M-Block, University Road, \\ Westville Campus, University \\ of KwaZulu-Natal 3629, \\ South Africa \\ Dates: \\ Received: 10 Feb. 2012 \\ Accepted: 13 July 2012 \\ Published: 22 Nov. 2012 \\ How to cite this article: \\ Ruggunan, S., 2012 , \\ 'The labour market for \\ histopathologists in KwaZulu- \\ Natal: emerging issues', \\ Health SA Gesondheid 17(1) \\ Art. \#646, 8 pages http:// \\ dx.doi.org/10.4102/hsag. \\ v17i1.646
}

C 2012. The Authors Licensee: AOSIS OpenJournals. This work is licensed under the Creative Commons Attribution License.
The aim of this article was to assess the factors that shape the labour market for histopathologists in KwaZulu-Natal (KZN), South Africa. The literature on the labour market and labour processes of histopathologists is dominated by North American and European literature. This gap is most acutely felt on the African continent. This article attempts to fill this gap by shifting the focus towards understanding the factors that shape the professional milieu and labour market for histopathologists in South Africa. This study through a qualitative, descriptive and contextual design engaged in in-depth interviews with $70 \%$ of the population of histopathologists in KZN. The interviews were analysed thematically. These interviews were triangulated against labour market statistics for histopathologists in South Africa as well as a range of documentary evidence. The outcome of the study has demonstrated four key challenges facing the labour market for histopathologists: racial inequities persist in the labour market, gender inequities also persist, there is unfettered public-private sector mobility, and poor curriculum design at medical school level accounts for a limited input of registrars into the profession. The article concludes that there needs to be a shift from only studying the labour market and work organisation of clinical doctors to empirical research on the role of medical laboratory specialists in the healthcare chain, which will render South African histopathologists and their work visible. A set of labour market interventions is also suggested.

Die artikel bestudeer die faktore wat die arbeidsmark vir histopatoloë in KwaZulu-Natal (KZN), Suid-Afrika beïnvloed. Die literatuur oor die arbeidsmark en arbeidsprosesse van histopatoloë word gedomineer deur Noord-Amerikaanse en Europese literatuur. Hierdie gaping is veral akuut op die Afrika kontinent. Die artikel poog om hierdie gaping te vul deur die fokus te verksuif na die faktore wat die professionele millieu en die arbeidsmark van histopatoloë in Suid-Afrika beïnvloed. Die studie het gebruik gemaak van 'n kwalitatiewe, beskrywende en kontekstuele ontwerp. In-diepte onderhoude is gevoer met $70 \%$ van die histopatoloë in KZN. Die onderhoude is tematies geanaliseer. Hierdie onderhoude is getrianguleer teen arbeidsmark statistieke vir histopatoloë in Suid-Afrika, sowel as 'n reeks dokumentêre bronne. Die uitkoms van die studie het vier belangrike struikelblokke geïdentifiseer wat die arbeidsmark vir histopatoloë in die gesig staar: rasse-ongelykhede duur voort in die arbeidsmark, so ook geslagsongelykheid, daar is vrylike beweging tussen die publieke- en privaatsektors, en 'n sleg ontwikkelde kurrikulum by mediese skole het lae toetrede getalle vir registrateurs in die professie tot gevolg. Die artikel kom tot die gevolgtrekking dat dit onvoldoende is om slegs die mark en werksoraganisasies van kliniese dokters te bestudeer - empiriese navorsing is ook nodig om die rol van die mediese labaratorium spesialiste in die gesondheidsorg ketting te bestudeer. ' $n$ Stel arbeidsmark ingrypings word ook voorgestel.

\section{Introduction}

The aim of this article is to identify factors impacting on the nature of the labour market for histopathologists (also known as anatomical pathologists) in KwaZulu-Natal (KZN), South Africa. The literature on the labour market for histopathologists is dominated by European and American studies, with a limited and neglected focus on the shape of the labour market in Africa (Bates \& Maitland 2005). Given this context, this article is an attempt to fill the gap in the empirical record by shifting the focus towards understanding the nature of the labour market for histopathologists outside of Europe, North America and other industrialised economies.

A review of official labour market statistics was conducted. This was followed up with in-depth interviews with $70 \%$ of the population of histopathologists in the South African province of KZN. These included histopathologists in both the private and public sectors. Whilst the empirical work conducted for this article is restricted to KZN, key extrapolations to the national South African labour market are possible. 


\section{Problem statement}

The World Health Organisation admits that data regarding certain categories of healthcare specialists in South Africa are much less available, and in some cases negligible (Pillay 2009; World Health Organisation 2011). This is demonstrated in the lack of precise data on the labour market for South African histopathologists. This situation is further compounded by inaccurate data-keeping by the Health Professionals Council of South Africa (HPCSA) of the actual number of medical laboratory specialists registered and practising in the country. This makes it difficult to estimate the magnitude of any shortage or to manage the consequences of a shortage of these medical specialists. In addition, the labour process of histopathologists is largely invisible in South Africa, with the majority of research focused on clinical health practitioners.

Laboratory medicine is vital in preserving and protecting health, as it enables the identification and measurement of biochemical and molecular risk factors, markers of genetic susceptibility and predictors of disease-related complications (Plebani \& Lippi 2010:93; Guidi \& Lippi 2006). The term 'medical laboratory specialist' incorporates a broad spectrum of categories of doctors that oversee and perform laboratory investigations for patients. There are many different types of medical laboratory specialists, including haematologists, anatomical pathologists, chemical pathologists, virologists, and microbiologists. Anatomical pathologists, also known as histopathologists, are specialists that are concerned with the tissue diagnosis of diseases (Royal College of Pathology of Australia 2011). The primary function of an anatomical pathologist is the diagnosis of biopsies derived from patients. Once a tissue biopsy is conducted by a doctor, it is sent to an anatomical pathologist for diagnosis. Histopathologists also conduct postmortems to ascertain cause of death where no foul play is suspected.

Fieldwork for this study has revealed a profound shortage of histopathologists in KZN, specifically in the public sector. The research question that guided this research therefore was: What factors account for the current nature and characteristics of the labour market for histopathologists in $\mathrm{KZN}$ ?

\section{Research objective}

The research objective for this research was to explore and ascertain the specific factors that contribute to the shape and characteristics of the labour market for histopathologists in KZN.

\section{Significance of the study}

The study provides novel qualitative data on the nature of the labour market for histopathologists. The aim is to shift beyond the quantitative data which only describe the population and do not provide insights into deeper qualitative reasons as to why the labour market is shaped as it is. Further, the study shifts the focus from clinical health workers to laboratorybased health workers, and is the first study of its kind to investigate empirically the nature of the labour market for histopathologists in KZN and South Africa. In this way the study renders visible an invisible sector in the chain of health care, and speaks to ways in which labour markets are shaped. It also posits possible solutions to the shortage of histopathologists in the country. As such, the study has potential policy implications for human resources strategies.

\section{Research method and design Design}

A case study was identified as the most appropriate research design for this study due to its advantages in qualitative research. Case study designs are exploratory and descriptive, thus suiting the purposes of this study. Case studies facilitate a deeper understanding of complex social phenomena and are more applicable to real-life situations (Yin 2009). Case studies can be qualitative, exploratory and contextual. Case study designs are supported by researchers that aim to explore the complex nature of healthcare work and issues (Siu 2009; Ng \& White 2005). Given that understanding the ways in which labour markets are shaped is necessarily complex, a case study design is appropriate.

\section{Participants and sampling}

The population for this research was 23 anatomical pathologists employed in both the public and private sectors in KZN. Purposeful and snowball sampling were used to select the participants. This technique allowed the researcher to select participants who were willing to participate as well as those who would offer rich data and thick descriptions of the central themes under investigation. Given the small population size, snowball sampling assisted in identifying participants. The key criterion for the sampling was that participants had to be qualified anatomical pathologists that were willing to be interviewed.

\section{Sample realisation}

Sixteen anatomical pathologists were interviewed, one female and 15 male. Their experience ranged from being newly qualified to having over 22 years of work experience. At the time of the study seven worked in the private sector and nine in the public sector. The sample represented $70 \%$ of the population of histopathologists in KZN.

\section{Sample size}

Qualitative research seeks to gain complex information and thick descriptions from participants (Neuman 2007) about social phenomena in order to provide insights into them. As such the concern is less with obtaining large sample sizes but rather with samples that are able to validly answer the research questions. The sample size for this study was $70 \%$, which is representative; the entire population was initially approached and $70 \%$ agreed to be interviewed. The researcher made a subjective determination that data saturation had been reached, and it was unlikely that the remaining 30\% of the population would have introduced new themes to be investigated. 


\section{Data collection method}

The primary data collection method was the use of face-to-face in-depth interviews. A total of 16 interviews were conducted. The length of each interview varied from 45 minutes to two hours. Interviewing is a method of collecting data from respondents in order to seek information on issues of interest (Sekaran 2010). Put simply, an interview is a 'purposeful discussion' between two or more people (Saunders, Lewis \& Thornhill 2003). An in-depth interview is a strategy that involves thorough individual interviews by the researcher in an attempt to investigate specific perspectives on particular ideas or situations and areas of interest and to record responses (Monette, Sullivan \& de Jong 2008: 158, 172).

An interview guideline was designed to ensure that the same themes and questions were asked of all participants. Probing during the interview process was also used on several occasions; these are used to further explore the responses or answers of participants in relation to the research problem (Saunders et al. 2003). The interviews were recorded using a high-quality digital voice recorder and thereafter transcribed. The interviewer made a conscious effort to avoid interviewer bias by making notes of what such biases are and designing the questions and interview to avoid them. The interview schedule was also checked by an independent researcher for possible bias.

A secondary data collection method was obtaining and making sense of labour market statistics provided by the HPCSA. The data had to be 'cleaned' and pivot tables were created in Excel by the researcher to make sense of the 'raw' descriptive statistics provided by the Council.

\section{Data analysis}

The principal construct used for analysing data in this study was thematic analysis, which involves a search for themes that develop in relation to the investigation and description of a phenomenon (Fereday \& Muir-Cochrane 2006). Thematic analysis is the underlying foundation for qualitative analysis, and may be defined as a process for the identification, analysis and reporting of 'patterns' or themes within data (Braun \& Clarke 2006). Flexibility is immensely beneficial in thematic analysis. It serves as an efficient research tool by way of its theoretical freedom that provides detailed and complex data (Braun \& Clarke ibid.). In other words, this procedure requires the identification of themes by way of examining and repeatedly reading the data (Fereday \& Muir-Cochrane ibid.). Patterns and themes are recognised and interpreted from the data, forming the basis for analysis (Fereday \& Muir-Cochrane ibid.). Thomas and Hardens (2007) provide an example of the steps involved in thematic analysis, which involves three stages: free line-by-line coding of findings of primary studies; organising codes into areas to create themes; and construction of analytical themes.

Themes were manually coded in this case study (categorised into different themes or patterns), and developed through consistent and thorough reading of all the interview transcripts numerous times. Themes were chosen according to their relevance to the research questions of the study. Some of the themes identified during thematic analysis include causes of mobility, effects or implications of mobility, the extent of mobility, racism, gender issues, and training opportunities, to name but a few.

\section{Context of the study}

The fieldwork for the study was conducted at three sites. Interviews with private sector histopathologists were conducted in the board rooms and offices of their respective workplaces. In the case of public sector histopathologists, interviews were conducted in a seminar room on the Howard College Campus of the University of KZN (UKZN), and in one instance at a coffee shop at the Albert Luthuli Central Hospital.

\section{Ethical considerations}

Ethical permission to undertake the research was obtained from the Academic Ethics Committee of the UKZN. Each participant signed an informed consent form which allowed them to withdraw from the study at any point without repercussion. Pseudonyms have been used to disguise the real identities of the participants.

\section{Trustworthiness}

Triangulation is essential to ensure validity of information or data (Creswell 2007; Olsen 2004) and was used in this study. Triangulation concerns the use of more than one method and the use of multiple, diverse sources of data in studying any social phenomenon in order to provide corroborating evidence (Bryman \& Bell 2007:412). For this project forms of secondary data, which have been outlined in the previous sub-section, such as labour market statistics, professional newsletters, academic journal articles and other forms of documentary evidence, were used to verify or cross-check data collected by the researcher. In addition, the final report was proofread by an independent anatomical pathologist to ensure validity. This is in keeping with peer examination to ensure trustworthiness in the research process.

\section{Discussion of results}

Under the broad research question of 'What are the contributing factors that shape the labour market for histopathologists in KZN?', the following four themes emerged from the interview data: racial inequalities, gendered inequalities, unfettered public to private sector mobility, and poor curriculum design at medical school level.

\section{The labour market for histopathologists}

In South Africa there are officially 245 anatomical pathologists, 115 haematologists, 28 virologists and 115 chemical pathologists (HPSCA 2011) However, these figures are exaggerated and inaccurate. The register does not reflect the number of specialists that are practising outside the country but maintain their national registration, nor does it 
reflect those that have retired from practice but maintained their registration. If the figure of 245 were to be accurate, it would reflect a ratio of one histopathologist to every 2 million people in the country. Fieldwork in KZN revealed that there are only 23 histopathologists as opposed to the 26 indicated in the official statistics. The ratio of specialist to population in KZN therefore is one per 10819130 people (Statistics South Africa 2011). Four emerging themes surfaced from the interview data that indicate possible challenges impacting on the shortage of histopathologists both provincially and nationally, and these are discussed below.

\section{Curriculum design}

Firstly, there is a sense amongst participants that the curriculum at the UKZN medical school needs to more fully incorporate histopathology as an independent discipline, so that medical students develop a better grasp of the discipline and the possibilities it may offer as a career choice. The removal of laboratory disciplines from the medical curriculum also affects the quality of medical laboratory specialists produced. For example, the removal of anatomical pathology as a third-year undergraduate model has also affected the quality of specialists qualifying in the field. When questioned about the consequence of removal of the module from the undergraduate curriculum, a senior anatomical pathologist replied:

'It is actually sad because it has created poor-quality doctors and you speak to any of the lecturers, you speak to the Dean, they will admit that the quality of doctors qualifying now is different from the past because they are not, the training that we had was more thorough and gave you exposure to basic disciplines.' (Dr A, interview, 17 May 2011)

Therefore, besides facilitating the shortage of anatomical pathologists in $\mathrm{KZN}$, the lack of exposure to the discipline has also reduced the quality of specialists that are qualifying. Medical students in their undergraduate studies lack intensive training in laboratory disciplines, and as a result qualify with less expertise and less experience (Dr A, interview, 17 May 2011). Follow-up interviews with UKZN medical students confirmed this perception, with students indicating that they were not aware that the specialty even existed as a stand-alone discipline. A consequence of this is an insufficient input of registrars into the discipline.

Similarly, another participant confirmed the lack of exposure to the discipline at an undergraduate level:

'In the clinical years, which are your last four years of the six year training period, and in your internship, you get exposed to all the surgical disciplines, the medical disciplines, paediatrics, obstetrics... but you never get exposed to pathology in the working environment. You get exposed to the reports that come back to you but you never go and visit the laboratories because you are based in the wards the whole time. And so when people go from their internship let's say and select something to specialise in, they go with one of the disciplines that they have been exposed to over the last couple of years, which would be one of the clinical specialities such as surgery or obstetrics or paediatrics something that they have enjoyed and not really laboratory medicine. They are not exposed to it.' (Dr B, interview, 04 May 2011)
Clearly the issue of the discipline being fragmented and not being presented as a viable career path does impact on students' choice of postgraduate study. This in turns leads to insufficient numbers of students feeding into the laboratory disciplines and practising as medical laboratory specialists. This further reflects a clinical bias in the design of the curriculum, with emphasis being placed on medical disciplines that are seen to have direct interaction with patients. However, as the following participant states, there is a misperception that doctors in the laboratory disciplines are not directly invested in patient care:

'I think it's a field that people are not keen on because the perception is that it takes them away from patients. I am talking about clinical doctors, it takes them away from patients and it's a field that you have to get a feel for so to speak ... as a medical doctor there is that mindset of working with patient is real medicine, therefore this perception of a lack of patient care becomes a deterrent.' (Dr B, interview, 04 May 2011)

Medical students graduate with their undergraduate medical degrees and leave medical school without knowing that anatomical pathology is a viable field to specialise in. They do not consider anatomical pathology to be a major specialty that is needed and is in demand in South Africa. When questioned about the factors behind the failure to recruit new graduates into pathology, a former South African anatomical pathologist stated:

'So I blame the curricula, the people who design the curricula in all eight medical schools in this country who alienated pathology. So there needs to be change in that as well. The old didactic or greater exposure of undergraduates to pathology needs to be brought back. that needs to happen, otherwise we are just going to become a discipline that doesn't exist and pathological services are not only going to be outsourced to private but soon to other countries.' (Dr C, interview, 19 March 2011)

Changing of the modular system in medical school resulted in anatomical pathology being removed as a module and replaced with other modules that generally cover a holistic range of fields. There is no 'visual presence of anatomical pathology' (Dr D, interview, 24 August 2011). As empirical work by Rogerson (2007) has shown, there is a direct link between the ways in which medical curriculums are designed and their impact on recruitment and retention of medical specialists in South Africa. This theme needs to be explored further at national level with stakeholders involved in the design of medical curricula in South Africa, since it does have a direct impact on the shape of the labour market and the attendant shortage of histopathologists in the country.

\section{Race}

The subject of race and racism was another major theme that emerged during the interview process. The theme emerged as a response to questions on racial transformation of the labour market for histopathologists. The labour market for histopathologists both nationally and provincially in $\mathrm{KZN}$ is racially skewed. Nationally the discipline is White male-dominated, and in KZN it is Indian maledominated. This reflects historical apartheid legacies of training and employment. For example, the national labour 
market comprises 5\% Black, 9\% Indian and 61\% White histopathologists, with $25 \%$ of pathologists remaining racially unclassified. The most likely reasons for this last cohort of racially unclassified pathologists are that they represent $25 \%$ of pathologists who are 'missing' from the country and practising overseas, and hence difficult to trace and classify. Nonetheless they remain on the register. Further, this portion of histopathologists could represent an ageing cohort of specialists who have not been removed from the register despite no longer practising. If this is the case, then most of the $25 \%$ would be White South Africans, further inflating the percentage of White histopathologists (interview data: HPSCA official). This is also in keeping with national trends of an ageing White South African population (National Planning Commission of South Africa 2011).

However, an emerging post-apartheid trend is the preference for many Black medical doctors to opt for specialties that are perceived to offer quicker occupational returns in terms of remuneration and career mobility. These returns are perceived to lie within the domain of clinical specialties as opposed to laboratory-based ones.

Dr E, also a public sector anatomical pathologist, concurs with his colleague Dr F as he asserts the inclination of African doctors toward financial gains as opposed to specialisation:

'Most people want to practice immediately as GPs because they need to earn a living and they need to make money. Whereas if you specialise, it is a sacrifice for four to five years in terms of your time, your family life as well as your income ... But I think right now in general, I think across the board, most specialities find it difficult to attract black doctors to specialise.' (Dr E, interview, 21 May 2011)

In 2011 there were only three Black medical laboratory specialists practising in $\mathrm{KZN}$, all in the private sector. Black female histopathologists are a rarity, with only three in South Africa. In addition to the 'quick occupation returns' thesis is the experience of overt and covert forms of racism at sites of practice and training. One of the participants stated that challenges of covert racism were more prevalent in the public sector than the private sector (interview, anonymous 2011). Racism is further made complex by the lack of Black role models or senior histopathologists in both the public and private sectors (interview, anonymous). This is less of an issue in clinical specialties that have comparably higher levels of Black practitioners at senior levels.

Dr E, an anatomical pathologist in the public sector, illustrates the racial situation of the South African environment from his experience of attending conferences as well as Pretoria's eventual accomplishment:

'The first thing is that there wasn't a lot of exposure to it so I think just by, the best take on it is when we go for national congresses. And this is just a rough estimate but if you go for your major sessions, you would say about $80 \%$ are White, then about $15 \%$ are Indian and now over the last few years we are getting Black pathologists who are now qualifying. Just as an example, in Pretoria last year was the first year that they graduated a Black anatomical pathologist. Natal has a history of producing Black anatomical pathologists, we have been doing it for years. Most of them migrate out of the province or country. But I mean it was 2010 and that was the first time that they produced one.' (Dr E, interview, 21 May 2011)

Dr $G$, an anatomical pathologist in the private sector of $\mathrm{KZN}$, admits that there is racial inequality in the laboratory discipline. He then says that training is conducted in the public arena, so if there is disproportion there it will filter into the private arenas:

'The racial distribution is skewed everywhere, not only in anatomical pathology but obviously it's more exaggerated in the laboratory industry.' (Dr G, interview, 20 June 2011)

He also implies that there are three factors that contribute to the shortage of African pathologists: firstly, the deliberate and racialised recruitment strategies of academic departments, when they only recruit people of their own race; secondly, the fact that South Africa's intake of African students at medical school is still disproportionate and has significantly stagnated the entrance of African people into medical schools, thus creating a slow progression toward specialising; additionally Dr $\mathrm{G}$ says that based on his experiences, African doctors were not encouraged to specialise beyond their initial qualifications:

'African people are not encouraged to specialise ... but in this day and era you know that shouldn't be happening as much. But the main thing is that African doctors are not encouraged to specialise.' (Dr G, interview, 20 June 2011)

As Dr F argues:

'With the African background, when you are finished medical school, you are expected to support the rest of your family. So if you are coming to specialise, you earn less than a GP. So it will be a five-year delay and your family will be expecting you to do things for them. So the background plays an important role.' (Dr F, interview, 18 May 2011)

This suggests that the poor economic backgrounds that African children come from has restricted their enrolment into specialties, because as soon as they become doctors their main aim is to begin practising, so as to pay the study loans they made use of as well as beginning to provide for their families.

\section{Dr G further contends:}

'This is Durban ... And it's in South Africa. You know the effects of the past have not faded. It's going to a very long time. And can you imagine if we are being, if I can experience it as a doctor, how much more does a guy who is a labourer.' (Dr G, interview, 20 June 2011)

Black histopathologists who were interviewed expressed a desire for racial transformation of the discipline in the country as a whole. The public sector is particularly important in this regard, since it is responsible for the recruiting and training of new registrars (interview, anonymous). The issue of race, racism and transformation needs to be explored in future research.

\section{Gender}

The specialty is male-dominated both nationally and in $\mathrm{KZN}$, with only seven of the 23 pathologists in KZN being female. 
This trend is also evident at national level, with $37 \%$ of histopathologists being female. Given the relatively stable working hours, working time flexibility and ability to work from home in some cases, the discipline should be more attractive to female candidates, particularly those who are mothers. As one interviewee explained:

'As a mother and a wife it is easier to have your certain hours so that you have your second job to go home to once you leave here [the office/laboratory].' (Dr H, interview, 20 June 2011)

However, interviewees indicated that despite the conditions of work being perceived as more favourable by those wanting more of a work-life balance, the reality is different. There is an intensification of the labour process. Firstly, the interview data revealed that there are higher levels of productivity expected within the same number of working hours, in both the public and private sectors. Secondly, histopathologists in the public sector have a range of other duties, such as teaching, research and training. These extend the hours of work and are compounded by lack of human resources. It is often difficult to maintain a work-life balance in this context (interview data, Dr I, 26 May 2011; Dr J, 19 May 2011).

Literature indicates that work-life balance is a key criterion for women in their choice of professions (Richman, Civian, Shannon \& Brennan 2008). The erosion of work-life balance in the practice of histopathology was the reason most often cited by interviewees for them leaving the public sector. However, as one interviewee stated, the organisational norm within the department is for histopathologists to have to work from $07 \mathrm{~h} 00$ until $18 \mathrm{~h} 00$. This norm is a strategy to assist in managing the high workloads in the public sector, and could account for a general dissuasion of both men and women from choosing to train in the specialty.

\section{Public sector to private sector mobility}

The level of mobility out of the public sector of medical laboratory specialists and into the private sector is prevalent nationally and acutely expressed in KZN. This is a key shaper of the labour market for pathologists. Official HPSCA statistics reflect that of the 23 histopathologists practicing in $\mathrm{KZN}$, nine (39\%) practice in the public sector and $14(61 \%)$ in the private sector. The HSPCA is unable to provide national statistics on the national split between private and public, and this exploratory study is limited to KZN. However, given the national trend for $63 \%$ of medical specialists to practice in the private sector, one can conjecture that this trend is applicable to histopathologists as well (Breier \& Wildschut 2006; Breier \& Erasmus 2009).

The trend is for over $80 \%$ of histopathologists who train in the KZN public sector to leave to go to the private sector. Once pathologists qualify in the public sector, they leave as soon as possible (interview data, Dr K, 30 August 2011; Dr A, 17 May 2011). Histopathologists in the private sector estimate that eight out of every 10 specialists leave the public service upon qualifying (interview data, Dr A, 17 May 2011; Dr L, 24 April 2011). It must be noted that the small population of pathologists between sectors also facilitates movement out of public sector. As Dr C explained:
'Our discipline is very specific so we know everyone in private, I mean people who are partners in the private laboratories trained in our department and when they need someone and they do, they just pick up the phone and ask if you want to come, if you want a job. And so the migration levels are high.' (Dr C, interview, 19 March 2011)

However, mobility out of the public sector is dependent on supply and demand in the labour market. For example, it is very dependent on the number of posts available. Given the low turnover rates in the private sector, saturation levels are easy to reach. There have also been attempts in the public sector to offer more competitive salaries as a retention strategy (interviews, Dr P, 04 May 2011; Dr Q, 24 August 2011 Dr K, 30 August 2011). A more recent development is to compel new registrars to serve two years in the public sector before being allowed to leave (interview data, Dr B, 04 May 2011; Dr J, 19 May 2011). This is a relatively new development, which will ensure a stable cohort of histopathologists in the public sector over the next few years.

There is extremely limited mobility of histopathologists from the private sector into the public sector. The key reason for such mobility would be if these specialists wanted to train to super- specialise or sub-specialise in the discipline ( $\operatorname{Dr} \mathrm{N}$, interview, 05 May 2011).

In order to understand the trend to shift between sectors and develop any effective human resources retention, an analysis of the choices made by histopathologists was made. Firstly, $63 \%(n=10)$ of histopathologists interviewed indicated financial reasons as the core reason to migrate out of the State sector. This is despite the shift by the State to offer more competitive salaries. Secondly, $44 \%(n=7)$ of the sample interviewed indicated unsatisfactory working conditions as a reason for the mobility. Thirdly, lack of working time flexibility and lack of work-life balance was indicated by $38 \%$ $(n=6)$ as a reason for leaving the public sector. Fourthly, 19\% $(n=4)$ of those interviewed indicated a lack of career pathing as a reason to leave.

A number of effects are caused by the mobility of medical laboratory specialists between sectors. Histopathologists must still manage with the remaining work left behind even after colleagues have left, which results in strain being experienced at all levels of the laboratory.

This in turn means that pathologists experience an escalation of stress and strain, as indicated by the literature (Beckerling \& Brunner 2003). This strain filters to technologists and administrative staff as well (interview data, Dr A). Therefore there is an increase in workload and stress (interviews: Dr O, 19 May 2011; Dr D, 24 August 2011; Dr F, 18 May 2011; Dr B, 04 May 2011). Subsequently the mobility of medical laboratory specialists from the public to the private sector may also influence others to leave, resulting in a self-fulfilling prophesy of high turnovers (Dr M, interview, 30 May 2011).

Perhaps the most profound consequence of this mobility is its impact on patient care, as there are inevitable delays in 
diagnosis. Dr M sketches the turnaround time for the public sectors as well as the consequences of a delayed consultation and result:

'I know in the State, and we have got all these complaints about it, it takes about three weeks even up to a month to get a result. Which I think as a pathologist is criminal. You can't have a patient with a breast lump or a cancer waiting for one month to get a diagnosis. Whereas in the private sector, within three or four days that patient is treated and had surgery and had chemotherapy or radiation therapy, whatever it is.' (Dr M, interview, 30 May 2011)

For example, the turnaround time for diagnosis increases, and this delay forces doctors to put further action for patients on hold as they require the results of tests such as biopsies. This observation is supported by Dr E, who indicates that:

'And because of the shortage, the turnaround time takes too long. We release results, it takes too long to release results, and so doctors have to wait for us before they can act. So waiting times are too long. So even though patients may have cancers which obviously require a treatment, we can't be efficient and offer them the best treatment because there is just a lack of pathologists in the country.' (Dr E, interview, 21 May 2011)

This also relates to the work of Ndihokubwayo Kasolo, Yahaya, \& Mwenda (2010), who stated that a shortage of laboratory staffing increases delays in diagnosis. In other words, there will now be fewer pathologists doing the same amount of work.

Importantly, anatomical pathology is closely associated with accuracy, turnaround time and completeness (Dr D, interview, 24 August 2011). Therefore there are approximately two doctors doing the work of 10 people, which will have many adverse results (Dr D, interview, 24 August 2011). Thus a possible implication of such a scenario, apart from delays in diagnosis or increased workloads and stress, could be misdiagnosis. Literature demonstrates that increased pressure, stress and exhaustion may lead to higher risks of medical error (Beckerling \& Brunner 2003; Bersch 2003; Blanckaert 2010), which is a strong possibility amongst overworked medical laboratory specialists in South Africa. A further consequence is the loss of expertise and experience from the public sector as histopathologists migrate from one sector to another (Dr D, interview, 24 August 2011).

The underlying effect on the overall health system is that there is a greater burden placed on fewer people (interview data, Dr O, 19 May 2011; Dr J, 19 May 2011). Another effect on the overall health system is that the training of registrars is also affected by the loss of medical laboratory specialists to the private sector. The number of registrars trained depends on the number of consultants available (Dr O, interview, 19 May 2011). Thus if a consultant leaves the public sector, the registrar may then have to book a time-slot with a consultant in order to discuss a case such as a bone marrow report before it is signed off. Furthermore, the consultant may then not always be available due to other working commitments already in place. Thus, if medical laboratory specialists are lost to the public sector, there is also a loss of the expertise to train registrars, as well as of those who have the authorisation to sign off reports and results (Dr O, interview, 19 May 2011).
The lack of flexibility and/or overwhelming workloads (Dr J, interview, 19 May 2011) in the public sector emerged as challenges confronting the public sector labour market for anatomical pathologists. One participant noted that if working hours became too stressful, to the extent that they infringed on one's social and personal life, then he would have to consider moving to the private sector (Dr J, interview, 19 May 2011). Leaving work late and having insufficient time at home with one's family is reason enough to move out of the public sector, he said. In addition, the challenges involved in the limited but mandatory teaching of medical students may also influence one's decision to leave the State sector. Therefore, whilst pathology is still taught in a limited way to medical students, the teaching of it remains time-consuming and a large part of the public sector histopathologist's job:

'I enjoy teaching although it's a challenge. You are lecturing to students. Especially with the younger generation being so different. You are lecturing to students and someone is making jokes and someone is talking on their cell phone and someone is talking and sharing their own jokes. So that is a great challenge and I don't know how long I will be able to handle that ... However if these, if it becomes more challenging I mean, I may consider my other options like either giving up teaching or moving over to private.' (Dr J, interview, 19 May 2011)

Clearly the unfettered mobility between the public and private sectors is a grave cause for concern. If the shape of the labour market is to be more equitable between the private and public sectors, then policy interventions need to take into account that pathologists switch sectors for reasons beyond remuneration. More importantly, the shortage of pathologists in the public sector has a profound consequence for the nature of health care for the majority of South Africans.

\section{Limitations of the study}

The focus of this study was to investigate key factors that shape the labour market for anatomical pathologists in KZN, South Africa. The research is therefore contextual and limited to the province of KZN. Future research should extend the study nationally to determine if the themes that have emerged provincially also emerge nationally.

\section{Recommendations}

Despite the exploratory nature of the research, four recommendations can be made to address the crisis facing the labour market for anatomical pathologists in $\mathrm{KZN}$ :

- Firstly, state human resources development policies need to be revisited to ensure increased retention rates in the public sector. Human resource policies for medical laboratory specialists must be adjusted to take this need into account. This study has shown that although salary is a factor that attracts specialists to the private sector, public sector salaries remain competitive, if not higher in some cases; however, pathologists are still driven to leave the public sector. Mobility is also influenced by flexibility and by level of autonomy (e.g. autonomy is said to augment staff's commitment to organisations (Gorman \& Sandefur 2011). A more effective human resources policy must take these non-monetary factors into account. 
- Secondly, a stable and growing labour market has to address racial and gender inequities in both the public and private sectors.

- Thirdly, the issue of medical school curriculum design must be examined and possibly reformed by stakeholders.

- Finally, increased public-private sector cooperation must be encouraged. It is strongly recommended that the levels of facilitation and mechanisms by which medical laboratory specialists interact with one another be increased. Interaction in this sense means sharing expertise, workloads, teaching of medical students and training of registrars. Facilitating the means for interaction between sectors will allow for the possibility to grow interaction in terms sharing of resources and improving patient care. Although there is limited interaction between public and private medical laboratory specialists at present, no formalised partnerships exist.

\section{Conclusion}

This article aimed to explore key challenges that are shaping the labour market for anatomical pathologists in KZN. The results demonstrated that there is a severe shortage of anatomical pathologists in KZN. This shortage is compounded by race and gender inequities in the labour market, as well as poor curriculum design and integration of the discipline into the UKZN medical school curriculum. Finally, the ceaseless migration from the public to the private sector needs to be addressed in a creative and cooperative way by stakeholders from both sectors. It is only in meeting these challenges that the long-term sustainability of the profession can be ensured.

\section{Acknowledgements}

The author is grateful for a grant provided by the National Research Foundation and the Department of Science and Technology of South Africa which made this article possible. The cooperation of the histopathologists in $\mathrm{KZN}$ is especially appreciated. I would like to acknowledge the assistance of my fieldworkers SS, NC and DM, as well as AK, who did the interview transcriptions.

\section{Competing interest}

The author declares that he has no financial or personal relationship(s) which may have inappropriately influenced him in writing this article.

\section{References}

Bates, I. \& Maitland, K., 2005, 'Are laboratory services coming of age in sub-Saharan Africa?', Clinical Laboratory Medicine 48(7), 48-51.

Beckerling, R. \& Brunner, R., 2003, 'The lab shortage crisis: A practical approach', Medical Laboratory Observer 35(6), 48-51.
Bersch, C., 2003, 'Combination of demands sharpens pinch of personnel shortage', Medical Laboratory Observer 35(4), 52.

Blanckaert, N., 2010, 'Clinical Pathology services: Remapping our strategic itinerary'. Chemistry Laboratory Medicine 48(7), 919-925. http://dx.doi.org/10.1515/ cclm.2010.194, PMid:20491600

Braun, V. \& Clarke, V., 2006, 'Using Thematic Analysis in Psychology', Qualitative Research in Psychology 3, 77-101. http://dx.doi.org/10.1191/1478088706qp063oa

Breier, M. \& Erasmus, J., 2009, Skills Shortages in South Africa: Case Studies of Key Professions, HSRC Press, Pretoria.

Breier, M. Wildschut, A., 2006, Doctors in a divided society: The profession and education of medical practitioners in South Africa, HSRC Press, Cape Town.

Bryman, A. \& Bell, E., 2007, Business Research Methods, 2nd edn., Oxford University Press, NY.

Creswell, J.W., 2007, Qualitative Inquiry and Research Design, 2nd edn., Sage Publications, Thousand Oaks.

Fereday, J. \& Muir-Cochrane, E., 2006, 'Demonstrating Rigor Using Thematic Analysis: A Hybrid Approach of Inductive and Deductive Coding and Theme Development', International Journal of Qualitative Methods 5(1), article 7, viewed 01 July 2011 , from http://www.ualberta.ca/ iiqm/backissues/5_1/html/fereday.htm

Gorman, E.H. \& Sandefur, L.R., 2011, “'Golden Age”, Quiescence, and Revival: How the Sociology of Professions Became the study of Knowledge-Based Work', Work and Occupations 38(3), 275-302. http://dx.doi.org/10.1177/0730888411417565

Guidi, G.C. \& Lippi, G., 2006, 'Laboratory medicine in the 2000s: Programmed death or rebirth?', Clinical Chemical Laboratory Medicine 44 (8), 913-917. http://dx.doi. org/10.1515/CCLM.2006.168

Health Professionals Council of South Africa (HPSCA), 2010, '2010 Registered Practitioners', viewed 09 February 2011, from http://www.hpcsa.co.za/ downloads/statistics/2010_registered_practitioners_stats.xls

Monette, D.R., Sullivan, T.J. \& De Jong, C.R., 2008, Applied Social Research: A Toll for the Human Sciences, 7th edn., Northern Michigan University, Marquette, MI.

National Planning Commission of South Africa, 2011, National Development Plan: Vision for 2030, Pretoria, National Planning Commission.

Ndihokubwayo, J.B., Kasolo, F., Yahaya, A.A. \& Mwenda, J., 2010, 'Strengthening public health laboratories in the WHO African region: A critical need for disease control', African Health Monitor 12, 47-52.

Neuman, W.L., 2007, Basics of Social Research: Qualitative and Quantitative Approaches, Pearsons, WI.

$\mathrm{Ng}$, C.K.C. \& White, P., 2005, 'Qualitative research design and approaches in radiography', Radiography 11(3), 217-225. http://dx.doi.org/10.1016/j. radi.2005.03.006

Olsen, W. 2004, 'Triangulation in Social Science Research: Quantitative and Qualitative Methods can really be mixed', Causeway Press, viewed 01 June 2011, from http:// www.ccsr.ac.uk/staff/Triangulation.pdf

Pillay, R., 2009, 'Work satisfaction of professional nurses in South Africa: A comparative analysis of the public and private sectors', Human Resources for Health 7(15), 1-10. PMid:19133140, PMCid:2631468

Plebani, M. \& Lippi, G., 2010, 'Is laboratory medicine a dying profession? Blessed are those who have not seen and yet have believed', Clinical Biochemistry 43 , 939-941. http://dx.doi.org/10.1016/j.clinbiochem.2010.05.015 PMid:20538540

Richman, A.L., Civian, J.T., Shannon, L.L. \& Brennan, R.T., 2008, 'The relationship of perceived flexibility, supportive work-life policies, and use of formal flexible arrangements and occasional flexibility to employee engagement and expected retention', Community, Work and Family 11(2), 183-197. http://dx.doi. org/10.1080/13668800802050350 PMid:2576907

Rogerson, C.M., 2007, 'Medical recruits: The temptation of South African health care professionals', Migration Policy Series 45, 1-39.

Royal College of Pathologists of Australia, 2011, What is Pathology?, viewed 01 June 2011, from http://www.rcpa.edu.au/Pathology.htm

Saunders, M., Lewis, P. \& Thornhill, A., 2003, Research Methods for Business Students, 3rd edn. Financial Times-Prentice Hall, London.

Sekaran, U., 2010, Research Methods for Business, A Skill Building Approach, John Wiley \& Sons, Boston.

Siu, W., 2009, 'Social Construction of reality, The tobacco issue', Public Health 19(1), 23-44.

Statistics South Africa (StatsSA), 2011, 'Census at a glance', viewed 20 August 2011, from http://www.statssa.gov.za/

Thomas, J. \& Hardens, A., 2007, Methods for the thematic synthesis of qualitative research in systematic reviews, ESRC National Centre for Research Methods, Philadelphia.

World Health Organisation 2011, 'World Health Statistics', viewed 03 August 2011, from http://www.who.int/whosis/whostat/2011/en/index.html

Yin, R.K., 2009, Case Study Research: Design and Methods, 4th edn., Sage Publications, Thousand Oaks, CA. 